\title{
Breeding drought tolerant cowpea: constraints, accomplishments, and future prospects
}

\author{
E. M. Agbicodo - C. A. Fatokun - S. Muranaka • \\ R. G. F. Visser - C. G. Linden van der
}

Received: 29 July 2008/ Accepted: 14 January 2009/Published online: 30 January 2009

(C) The Author(s) 2009. This article is published with open access at Springerlink.com

\begin{abstract}
This review presents an overview of accomplishments on different aspects of cowpea breeding for drought tolerance. Furthermore it provides options to enhance the genetic potential of the crop by minimizing yield loss due to drought stress. Recent efforts have focused on the genetic dissection of drought tolerance through identification of markers defining quantitative trait loci (QTL) with effects on specific traits related to drought tolerance. Others have studied the relationship of the drought response and yield components, morphological traits and physiological parameters. To our knowledge, QTLs with effects on drought tolerance have not yet been identified in cowpea. The main reason is that very few researchers are working on drought tolerance in
\end{abstract}

E. M. Agbicodo · C. A. Fatokun International Institute of Tropical Agriculture (IITA), Oyo Road, PMB 5320, Ibadan, Nigeria

E. M. Agbicodo - R. G. F. Visser - C. G. Linden van der Wageningen UR Plant Breeding, Wageningen University and Research Center, Wageningen, The Netherlands

\section{E. M. Agbicodo ( $\square)$}

The Graduate School Experimental Plant Sciences, Wageningen University, Wageningen, The Netherlands e-mail: eugene.agbicodo@wur.nl

S. Muranaka

Sabo Bakin Zuwo Road, PMB 3112, Kano, Nigeria cowpea. Some other reasons might be related to the complex nature of the drought stress response, and partly to the difficulties associated with reliable and reproducible measurements of a single trait linked to specific molecular markers to be used for marker assisted breeding. Despite the fact that extensive research has been conducted on the screening aspects for drought tolerance in cowpea only very few-like the 'wooden box' technique-have been successfully used to select parental genotypes exhibiting different mechanisms of drought tolerance. Field and pot testing of these genotypes demonstrated a close correspondence between drought tolerance at seedling and reproductive stages. Some researchers selected a variety of candidate genes and used differential screening methods to identify cDNAs from genes that may underlie different drought tolerance pathways in cowpea. Reverse genetic analysis still needs to be done to confirm the functions of these genes in cowpea. Understanding the genetics of drought tolerance and identification of DNA markers linked to QTLs, with a clear path towards localizing chromosomal regions or candidate genes involved in drought tolerance will help cowpea breeders to develop improved varieties that combine drought tolerance with other desired traits using marker assisted selection.

Keywords Vigna unguiculata L. · Drought tolerance - QTL mapping · Comparative genomics . Candidate genes - Marker Assisted Selection (MAS) 


\section{Introduction}

Agriculture is at a crossroad due to water scarcity, climate change, population pressure and environmental degradation. Cowpea [Vigna unguiculata (L.) Walp.] is one of the most important food legumes in the tropic and sub-tropic regions where drought is a major production constraint due to low and erratic rainfall (Singh et al. 1997). Of the world total area of about 14 million ha planted with cowpea, West Africa alone accounts for about 9 million ha (Singh et al. 2003a). With more than $25 \%$ protein in seeds as well as in young leaves (dry weight basis), cowpea is a major source of protein, minerals and vitamins in daily human diets and is equally important as nutritious fodder for livestock (Singh et al. 2003b). Among the popular crops grown in Central and West Africa, cowpea belongs to the inherently more drought tolerant ones (Singh et al. 1997; Ehlers and Hall 1997; Kuykendall et al. 2000; Martins et al. 2003). However, cowpea still suffers considerable damage due to frequent drought in the Savanna and Sahel subregion. Early maturing varieties escape terminal drought (Singh 1987), but if exposed to intermittent moisture stress during the vegetative growth stage, they perform very poorly (Mai-Kodomi et al. 1999a). Moreover, the early maturing cowpea cultivars tend to be very sensitive to drought that occurs during the early stages of the reproductive phase (Thiaw et al. 1993). Therefore, genetic enhancement of cowpea for drought tolerance by incorporating drought tolerance into early maturity cowpea lines represents the best and most cost-effective method for insuring sustainable and improved crop yield in variable and changing climates. Unstable rainfall in the early cropping season seems to be the pattern in the sub-region. There is also a rationale for incorporating tolerance to terminal drought, which is becoming more frequent in the subregion due to reduction in the duration of the rainy season. Unlike some other legume crops such as common bean (Blair et al. 2002; Schneider et al. 1997) and soybean (Mian et al. 1996, 1998; Specht et al. 2001) for which contemporary technological studies for drought tolerance are more advanced, cowpea is well studied for conventional genetics, but poorly characterized at the genomic level. Nevertheless, concerted efforts are being made worldwide to develop drought tolerant cowpea varieties (Turk and Hall 1980; Hall et al. 1997a) and good progress has been made at the International Institute of Tropical Agriculture (IITA) on breeding for enhanced drought (Okosun et al. 1998a, b; Singh et al. 1999a, b; MaiKodomi et al. 1999a, b). The current state of breeding research on drought tolerance in cowpea and possibilities for genetic enhancement of drought tolerance for optimal utilization of the genetic potential of the crop are discussed in this review.

\section{Dimension of drought on cowpea production in Central and West Africa}

Cowpea is one of the most ancient crops known to man. The crop originated and domesticated from Africa (Ng and Marechal 1985) and is widely adapted and grown throughout the world. Based on information available from FAO and from scientists in several countries, cowpea researchers at IITA estimated that cowpea is now cultivated on at least 14 million ha, with 3,722 thousand metric tons worldwide in 2003 (FAO 2004). However, Africa largely predominates in production as shown in Fig. 1. Central and West Africa alone account for about 9.3 million ha. A substantial part of cowpea production in the region comes from the drier areas of northern Nigeria (about 4 million ha, with 1.7 million tons), and southern Niger Republic (about 3 million ha, with 1 million tons) (Singh et al. 1993). Millions of African farmers grow cowpea in small scale farming. Some two hundred million Africans consume cowpea, and many possibly even a majority of the farmers are women. One of the most remarkable things about cowpea is that it thrives in dry

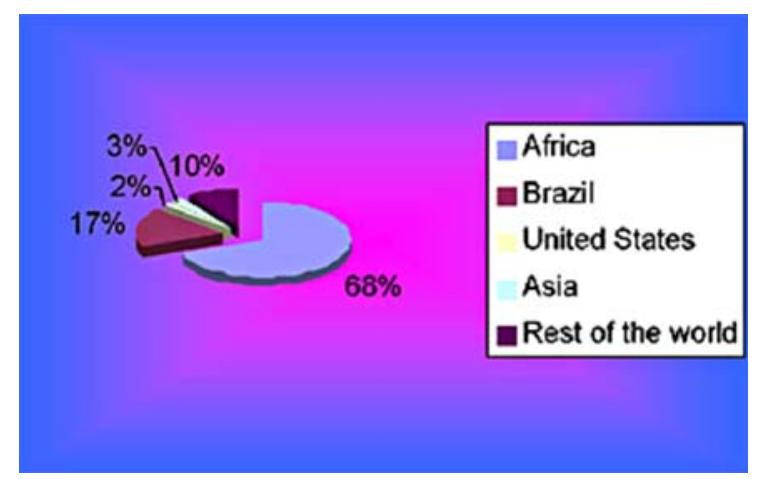

Fig. 1 Cowpea production throughout the world (dry grains) (FAO, http://www.fao.org/inpho/content/compend/text/ch32/ch32. $\mathrm{htm})$ 
environments and this makes it the crop of choice in the semi-arid/arid zones of West and Central Africa. Additionally, cowpea used to be the first crop harvested before the cereal crops are ready and therefore is referred to as "hungry-season crop". It is the most economically important indigenous African legume crop (Langyintuo et al. 2003) and is of vital importance to the livelihood of several millions of people in West and Central Africa. Cowpea is a most versatile African crop, it feeds people, their livestock and because of its ability in nitrogen-fixation, it improves soil fertility, and consequently helps to increase the yields of cereal crops when grown in rotation and contributes to the sustainability of cropping systems. Despite all its economic and cultural importance in Sub-saharan Africa, cowpea production is subjected to a wide range of biotic and abiotic constraints.

Hounam et al. (1975) and Glantz (1987) studied the effect of drought on hunger in Africa and reported that impact may range from slight personal inconvenience to endangered nationhood. Drought is the major abiotic constraint of cowpea production. Since cowpea is grown mainly in the dry savanna and Sahel areas with no irrigation facilities, irregular rainfall especially early in the season have adverse effects on the growth of the crop. The drier zones of northern Nigeria and Niger harbor the largest area of cowpea production in the world but yields are only between 100 and $500 \mathrm{~kg} \mathrm{ha}^{-1}$, despite its five times higher biological potential (Carsky et al. 2001). Niger is the second largest producer of cowpea after Nigeria yet it has the lowest average grain yield of $110 \mathrm{~kg} \mathrm{ha}^{-1}$ (Table 1). This is probably due to the fact that the whole country is located in the Sahel where rainfall is rather low. Moreover, drought conditions weaken the plants making them more vulnerable to disease infestations and insect pests attacks. As an African crop grown in resource-poor areas, few countries have cowpea improvement programs and the continent has very low average grain yield compared to for instance the United States (Table 1). However, concerted multidisciplinary efforts including genetics, physiology and biochemistry are being developed to unravel drought mechanisms in cowpea and to develop varieties better adapted to the climate changes in Sub-saharan Africa.

\section{Drought tolerance mechanisms}

Several factors and mechanisms operate independently or jointly to enable plants to cope with drought stress. Therefore drought tolerance is manifested as a complex trait (Krishnamurthy et al. 1996). Traditionally, drought tolerance is defined as the ability of plants to live, grow, and yield satisfactorily with limited soil water supply or under periodic water deficiencies (Ashley 1993). According to Mitra (2001), the mechanisms that plants use to cope with drought stress can be grouped into three categories viz drought escape, drought avoidance and drought tolerance. However, crop plants use more than one mechanism at a time to cope with drought.

Drought escape is defined as the ability of a plant to complete its life cycle before serious soil and plant water deficits occur. This mechanism involves rapid phenological development (early flowering and early maturity), developmental plasticity (variation in duration of growth period depending on the extent of water deficit) and remobilization of preanthesis assimilates. Drought avoidance is the ability
Table 1 Average yield $\left(\mathrm{t} \mathrm{ha}{ }^{-1}\right.$ ) of cowpea production in selected countries in West and Central Africa (1990-1999) and the United States (Langyintuo et al. 2003)

\begin{tabular}{llll}
\hline Countries & $\begin{array}{l}\text { Average yield } \\
\left(\mathrm{t} \mathrm{ha}^{-1}\right)\end{array}$ & Countries & $\begin{array}{l}\text { Average yield } \\
\left(\mathrm{t} \mathrm{ha}^{-1}\right)\end{array}$ \\
\hline Nigeria & 0.494 & Ghana & 0.663 \\
Niger & 0.110 & Mauritania & 0.331 \\
Mali & 0.244 & Côte d'Ivoire & 0.500 \\
Burkina Faso & 0.777 & Chad & 0.489 \\
Togo & 0.284 & Cameroon & 0.827 \\
Benin & 0.635 & Africa & 0.475 \\
Senegal & 0.341 & United States & 1.950 \\
\hline
\end{tabular}


of plants to maintain relatively high tissue water potential despite a shortage of soil-moisture. Plants develop strategies for maintaining turgor by increasing root depth or developing an efficient root system to maximize water uptake, and by reducing water loss through reduced epidermal (stomatal and lenticular) conductance, reduced absorption of radiation by leaf rolling or folding and reduced evapotranspiration surface (leaf area) (Mitra 2001). Drought tolerance is the ability of plants to withstand water-deficit with low tissue water potential. The mechanisms of drought tolerance are maintenance of turgor through osmotic adjustment (accumulation of solutes in the cell), increased cell elasticity and decreased cell size and desiccation tolerance by protoplasmic resistance.

However, all these adaptation mechanisms of the plant to cope with drought have some disadvantages with respect to yield potential. For instance, a genotype with a shortened life cycle usually yields less compared to a genotype with a normal life cycle. The mechanisms that confer drought avoidance by reducing water loss (such as stomatal closure and reduced leaf area) decrease carbon assimilation due to reduction in physical transfer of carbon dioxide molecules and increase leaf temperature thus reducing biochemical processes, which negatively affects yield. Plants try to maintain water content by accumulating various solutes that are nontoxic (such as fructans, trehalose, polyols, glycine betaine, proline and polyamines) and do not interfere with plant processes and that are, therefore, called compatible solutes (Yancey et al. 1982). However, many ions concentrated in the cytoplasm due to water loss are toxic to plants at high concentrations leading to what is termed a glassy state. In this condition whatever liquid is left in the cell has a high viscosity, increasing the chances of molecular interactions that can cause proteins to denature and membranes to fuse (Hartung et al. 1998). Consequently, crop adaptation to water stress must reflect a balance among escape, avoidance and tolerance while maintaining adequate productivity. Drought escape, avoidance, and tolerance mechanisms have been described in cowpea. However, the drought response pathways associated with these mechanisms are not yet understood, and the degree to which these adaptations operate jointly or separately to allow the crop to cope with drought still needs to be established.

\section{Drought tolerance mechanisms in cowpea}

Drought escape in cowpea

The increased incidence of drought in some cowpea growing areas has caused a shift to early maturing varieties (Mortimore et al. 1997). Early maturity of cowpea cultivars is desirable and has proven to be useful in some dry environments and years because of their ability to escape drought (Hall and Patel 1985, Singh 1987, 1994). Such early cultivars can reach maturity in as few as 60-70 days in many of the cowpea production zones of Africa. Earliness is important in Africa as early cultivars can provide the first food and marketable product available from the current growing season, and they can be grown in a diverse array of cropping systems. In addition to escaping drought, early maturing cultivars can escape some insect infestations (Ehlers and Hall 1997). The International Institute of Tropical Agriculture (IITA) and the Institut Senegalais de Recherches Agricoles (ISRA) have been at the forefront in developing early maturing high yielding and pest resistant cultivars. Selection for early flowering and maturity and yield testing of breeding lines under drought conditions has been used successful in developing cowpea cultivars adapted to low rainfall areas (Hall and Patel 1985; Cisse et al. 1997). Early maturity cowpea varieties (i.e., IT84S-2246, Bambey 21) that escape terminal drought have been released and widely adopted by African farmers. However, if exposed to intermittent drought during the vegetative or reproductive stages, these varieties performed very poorly. Efforts are therefore being made to breed cowpea varieties with enhanced drought tolerance for early, mid- and terminal season drought stresses. Different RIL populations are currently under evaluation for different traits including physiological, phenological and yields for drought tolerance at seedling and flowering/reproductive stages. These investigations aim at understanding which of the traits contribute importantly to yield under drought.

\section{Mechanisms of drought avoidance and tolerance in cowpea}

In cowpea, two types of drought tolerance have been described at the seedling stage using the wooden box 
technique (Mai-Kodomi et al. 1999a). At 15 days after the termination of watering, all the seedlings of the two susceptible lines TVu 7778 and TVu 8256, were completely dead. The "Type 1" drought tolerant lines like TVu 11986 and TVu 11979 stopped growth after the onset of drought stress and maintained uniformity, but displayed a declining turgidity in all tissues of the plants including the unifoliates and the emerging tiny trifoliates for over 2 weeks. All plant parts such as the growing tip, unifoliates and epicotyl gradually died almost at the same time. In contrast, the "Type 2" drought tolerant lines like Dan Ila and Kanannado remained green for a longer time and continued slow growth of the trifoliates under drought stress. With continued moisture stress, the trifoliates of these varieties started wilting as well and died about 4 weeks after drought stress started. The two types of tolerance responses by cowpea seedlings to drought stress indicate that cowpea genotypes evolved different mechanisms to cope with prolonged drought encountered in the semi-arid regions of Africa where the crop is believed to have originated. Closure of stomata to reduce water loss through transpiration and cessation of growth (for Type 1 drought avoidance) and osmotic adjustment and continued slow growth (drought tolerance in Type 2) have been suggested as the possible mechanisms for drought tolerance in cowpea (Lawan 1983; Boyer 1996). Cowpea is known as dehydration avoider with strong stomatal sensitivity and reduced growth rate (Lawan 1983). This seems to be the mechanism underlying the Type 1 reaction to drought of TVu 11986 and TVu 11979. The Type 2 reaction of Dan Ila and Kanannado appears to be a combination of three mechanisms; stomatal regulation (partial opening), osmotic control and selective mobilization with distinct visible differences in the desiccation of lower leaves compared to the upper leaves and growing tips (Mai-Kodomi et al. 1999a). It seems that the Type 2 mechanism of drought tolerance is more effective in keeping the plants alive for a longer time and ensures better chances of recovery than Type 1 when the drought spell ends. Both drought tolerant lines Dan Ila and Kanannado are local varieties commonly grown in the Sudano-Sahelian border areas of Nigeria and Niger Republic, indicating that in these areas farmers have selected cowpea varieties with good adaptation to drought. Similarly, Muchero et al. (2008) studied 14 genotypes of cowpea at seedling stage and confirmed the existence of significant genetic variation in response to drought stress. Genotypes, IT93 K-503-1 and IT98 K-499-39 were consistently most tolerant whereas CB46 and Bambey 21 were most susceptible. However, the differences in phenotypic responses to seedling-stage drought among the 14 genotypes were not consistently associated to drought tolerance. As for examples, genotypes IT82E-18(232) and Sutiva 2 showed rapid loss of unifoliates but were found at opposite ends of the drought tolerance spectrum. While, genotypes CB27 and Bambey 21 preserved unifoliates but Bambey 21 was highly drought susceptible and CB27 modereately susceptible under similar stress conditions. Somehow, these clear phenotypic responses to drought stress provide an opportunity for detailed studies of specific drought responses and select genotypes to be used as parents to study the inheritance of these specific responses.

The association between crop performance and carbon isotope discrimination $(\Delta)$ has been reviewed for cowpea, common bean, and peanut (Condon and Hall 1997). Genotypic differences in the potential grain yield of cowpea have been positively associated with $\Delta$, indicating that more productive genotypes have a higher photosynthesis rate resulting in higher internal carbon dioxide concentration in their leaves (Hall et al. 1997b; Condon and Hall 1997). Similar studies in other crops such as Pima cotton (Gossypium barbadense) and bread wheat (Triticum aestivum) have shown remarkable positive correlations between yield increases and increases in stomatal conductance ( $\mathrm{Lu}$ et al. 1998). The authors argued that the higher $\Delta$ in more productive genotypes of cowpea, cotton ( $G$. barbadense L.), and wheat (Triticum sp.) was probably due to their having more open stomata, which could have resulted in greater rates of photosynthesis due to diffusion effects (Condon and Hall 1997), or beneficial effects on the plant resulting from greater evaporative cooling (Lu et al. 1998). In favor to the more open stomata strategy under water stress, Cruz de Carvalho et al. (1998) compared physiological responses of cowpea and common bean genotypes and reported that the cowpea genotypes kept their stomata partially opened and had a lower decrease in their net photosynthetic rates than the common bean. Further investigations on these cowpea genotypes are needed to demonstrate whether there are significant positive effects on grain yield related to the partial opening of stomata under drought conditions. 
Several other mechanisms may partially explain the extreme dehydration avoidance of cowpea. The mechanisms through which cowpea is able to resist vegetative-stage drought may be related to the limited decrease of leaf water potential even under extreme drought. The lowest leaf water potential recorded for cowpea is -18 bar $(-1.8 \mathrm{MPa})$ (e.g., Turk and Hall 1980; Hall and Schulze 1980), whereas peanut has developed leaf water potentials under drought as low as -82 bar (-8.2 MPa) (Turner et al. 2000). Cowpea also changes the position of leaflets under drought (a drought avoidance mechanism). They become paraheliotropic and orientated parallel to the sun's rays when subjected to soil drought, causing them to be cooler and thus transpire less (Shackel and Hall 1979), which helps to minimize water loss and maintain water potential.

\section{Screening approaches for drought tolerance in cowpea}

Success in breeding for drought tolerance in cowpea has not been as pronounced as for many other traits (Singh et al. 1997). This is partly due to the lack of simple, cheap, and reliable screening methods to select drought tolerant plants and progenies from the segregating populations. The complexity of factors involved in drought tolerance could also have contributed to this. Nevertheless, cowpea genotypes with contrasting response to drought have been identified (Fig. 2). Researchers have proposed two approaches for screening and breeding for drought tolerance in plants. The first is the empirical or performance approach that utilizes grain yield and its components

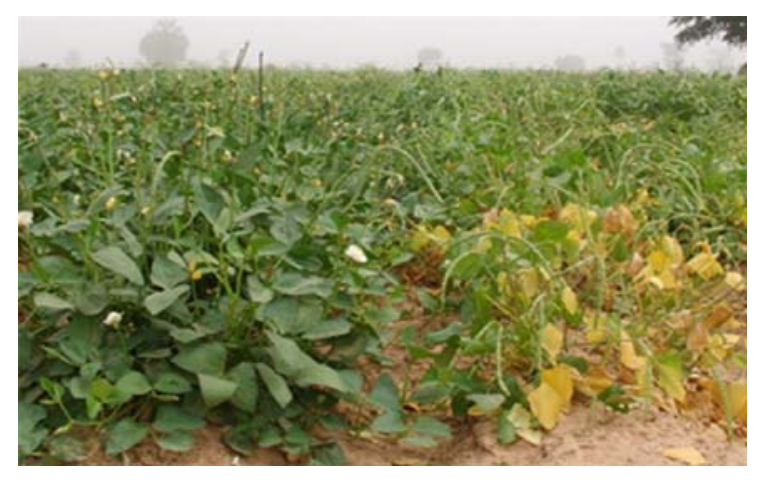

Fig. 2 Field screening of cowpea lines for drought tolerance. The plants on the left are IT98 K-205-8 (drought tolerant) and those on the right are, IT98 K-555-1 (drought susceptible) as the main criteria, since yield is the integrated expression of the entire array of traits related to productivity under stress. The second is the analytical or physiological approach that identifies a specific physiological or morphological trait that will contribute significantly to growth and yield in the event of drought. Modest progress in cowpea breeding for dry environments has been achieved by selecting for yield in breeding lines over several locations and years (Turk et al. 1980; Hall and Patel 1985; Selvaraj et al. 1986; Cisse et al. 1997; Hall et al. 1997b). However, these empirical approaches are slow, laborious, and expensive because of the need to assess the yield of a large number of lines across several locations and years, and the substantial variation from the effects of environment, and genotype-environment interactions (Blum 1985). As suggested by Blum (1983) and Fussell et al. (1991), the approach which combines selection for yield potential in favorable conditions with selection for the expression of physiological traits thought to be associated with drought tolerance under controlled, repeatable stress environments might be the most effective. This therefore requires the identification of specific traits associated with drought tolerance under adequate water management that are easy and reliable to measure (Fischer and Wood 1979).

\section{Morphological, biochemical and physiological traits for drought screening in cowpea}

Data on changes of morphological, biochemical and physiological traits in response to drought are available for some cultivars of Vigna unguiculata (Turk et al. 1980; Ogbonnaya et al. 2003; Matsui and Singh 2003; Slabbert et al. 2004). These traits include wateruse efficiency (WUE), water potential, relative turgidity, leaf gas exchange, relative water content (RWC), diffusion pressure deficit, chlorophyll stability index, and carbon isotope discrimination (Bates and Hall 1981; Turk and Hall 1980; Morgan et al. 1991; Hall et al. 1990, 1997b; Anyia and Herzog 2004; Souza et al. 2004). While comparing physiological responses of Phaseolus vulgaris and Vigna unguiculata to drought, Cruz de Carvalho et al. (1998) demonstrated that stomatal conductance to water vapor $\left(g_{\mathrm{s}}, \mathrm{mol} \mathrm{H}_{2} \mathrm{O} \mathrm{m} \mathrm{m}^{-2} \mathrm{~s}^{-1}\right)$ and net assimilation rates $\left(A, \mathrm{mmol} \mathrm{CO}_{2} \mathrm{~m}^{-2} \mathrm{~s}^{-1}\right)$ measured during and 
after a water stress treatment were reliable physiological parameters to use in early screening for drought tolerance in these species. Stomatal closure in the cowpea cultivar EPACE-1 was not related to any change in relative water content (RWC) indicating that early stomatal responses to substrate water depletion are not triggered by changes in leaf water content. Therefore, RWC alone can not be used as a drought indicator for cowpea. This also suggests the possible existence of a root to leaf communication, independent of the leaf water status that informs the shoot about changes in the root zone.

Following exposure of six cowpea varieties to drought in the upper $20 \mathrm{~cm}$ rooting zone, Kulkarni et al. (2000) compared the rate of abscisic acid (ABA) synthesis relative to total root mass and inherent variation per unit root mass. The authors observed that the intrinsic ABA synthesizing capacity rather than the root mass is responsible for the total ABA produced in the roots of the dry soil zone. The relationship between stomatal conductance and total root ABA was assessed and found to be negative $(r=-0.90, n=24, P=$ 0.05 ) suggesting that the intrinsic capacity of cowpea varieties for ABA synthesis could play an important role in regulating stomatal conductance in a drying soil and provide useful selection criteria for tolerance to drought stress in cowpea. In support to these results, stomatal regulation was reported to be the common strategy used by the five different cowpea genotypes to avoid dehydration both under glasshouse and field conditions (Hamidou et al. 2007). These authors measured the physiological, biochemical and agronomic responses to water deficit at flowering stage in five cowpea genotypes, Gorom local, KVX61-1, Mouride, Bambey 21 and TN88-63, that were grown in the glasshouse and the field. The five cowpea genotypes are known to differ in their susceptibility to water stress. Water deficit significantly increased the canopy temperature and the proline content of the five genotypes while gaseous exchanges and starch content decreased significantly. Yield components of the five genotypes, with the exception of seed number per pod, were also significantly affected. Number of pods and number of seeds per plant decreased after drought treatment by $57 \%$ in the glasshouse and by $64 \%$ in the field when compared to non-stressed plants. Genotypic differences were observed for both of the yield components. Genotype TN88-63 was more productive than the other four genotypes under glasshouse conditions, while under field conditions, Mouride and Gorom local proved to be more productive than KVX61-1, which in turn performed better than Bambey 21.

As an alternative to all the above investigations which focus on some specific physiological, biochemical and agronomic traits, an integrated approach which combines cellular water relations, rooting characteristics, leaf area and biochemical and morphological changes to screen cowpea for drought tolerance has been proposed by Slabbert et al. (2004). The different screening techniques that were tested included: the antioxidative response in the form of superoxide reductase (SOD), glutathione reductase (GR), ascorbate peroxidase (AP), proline accumulation, 2,3,5-triphenyltetrazolium chloride (TTC) assays, early drought screening at the seedling stage (wooden box technique), cell membrane stability (CMS), relative water content (RWC), leaf water potential (LWP), leaf area, chlorophyll $a$ and $b$ and carotenoid content and chlorophyll fluorescence (JIP test). Contrary to the results of Cruz de Carvalho et al. (1998), RWC was a good parameter to discriminate genotypes under water stress in cowpea (Slabbert et al. 2004).

An important morphological trait that may contribute to drought adaptation is the delayed leaf senescence (DLS) trait (Gwathmey et al. 1992). This trait enhances plant survival after a mid-season drought damages the first flush of pods, which enables a substantial second flush of pods to be produced. Cultivars with DLS also have enhanced production of forage because their leaves remain green and attached to the plant until harvest. The DLS trait allows the crop to stay alive through midseason drought and recover when rainfall resumes. Most importantly, DLS can be easily measured by visual observation using an appropriate scale.

In summary, based on the above findings from the different studies the following methods were most suitable for screening large number of cowpea lines for drought tolerance:
a. determination of chlorophyll fluorescence,
b. stomatal conductance measurements,
c. abscisic acid (ABA) measurements,
d. measuring free proline levels,
e. wooden box screening for drought tolerance at the seedling stage,
f. delayed leaf senescence (DLS). 


\section{Screening cowpea for drought tolerance at the seedling stage}

Singh et al. (1999a) suggested that different cowpea plant organs (leaf, shoot and root) should be used to screen for drought tolerance. The authors argued that different tissues have different responses to abiotic stress and should therefore be studied individually. This may enable the identification of tissue-specific genetic factors underlying the drought responses and the elucidation of parts of the drought response pathways possibly making breeding for drought tolerance easier. A simple screening method using the "wooden box technique" (Fig. 3) has been found suitable for identifying seedling drought tolerance in cowpea. This method eliminates the influences of the root system on drought tolerance, and permits nondestructive visual identification of shoot dehydration tolerance (Singh et al. 1999a). The method has proven to be efficient in screening for drought tolerance in different crop species (Singh et al. 1999b; Tomar and Kumar 2004; Slabbert et al. 2004; Ewansiha and Singh 2006). Field and pot testing of the plants of the different crop species demonstrated a close correspondence between drought tolerance in the seedling stage and reproductive stage. The wooden box screening method has been used to identify cowpea genotypes with contrasting responses to drought (Dan Ila, IT96D-602 and TVu 11986 which exhibit seedling drought tolerance and TVu 7778 which is susceptible). The

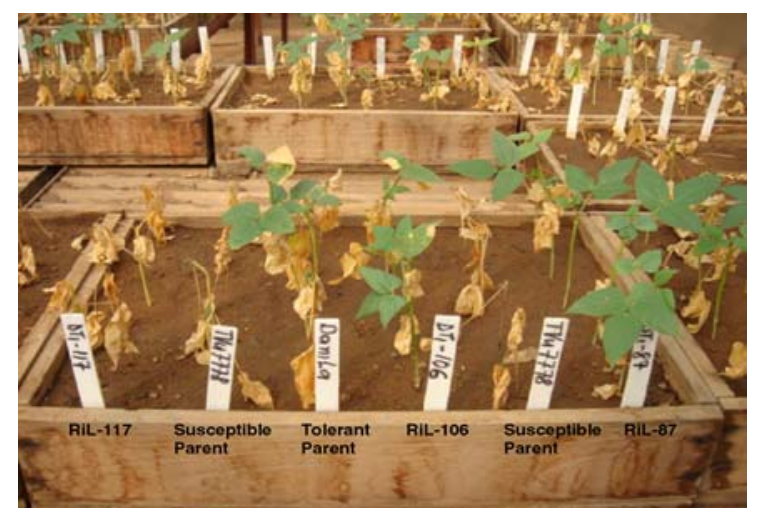

Fig. 3 Cowpea seedlings survival after 4 weeks of drought followed by 2 weeks of daily re-watering. The drought tolerant parent Dan Ila and RIL-106 had a 60\% survival rate, susceptible parent TVu 7778 and RIL-117 had 0\% survival, while RIL-87 had a $100 \%$ survival rate
RILs developed from the cross between Dan Ila and TVu 7778 have been evaluated for seedling survival under severe drought stress using the wooden box technique (not published). Seeds of four RILs and the two parents were planted randomly in straight rows in each wooden box. After emergence plants were thinned to one per stand. The boxes were watered daily with the same volume of water until the first trifoliate emerged and watering was completely stopped. After 4 weeks of water stress, when all the plants of susceptible parent TVu7778 appeared dead, watering was resumed. Variable number of seedlings recovered in some RILs and the tolerant parent 2 weeks after watering resumed (Fig. 3). Similar to the wooden box technique, small plastic pots were tested to separate plant root systems and to eliminate competition among genotypes for a communal water source while still maintaining the low space requirement that is characteristic of wooden screening (Muchero et al. 2008). The pot experiments in greenhouse were used to discriminate between 14 cowpea genotypes that exhibit significant genetic variation to drought stress at seedling. These authors emphasized that stem greenness, survival and recovery dry weights in greenhouse were the useful traits to screen cowpea genotypes for their ability to withstand drought stress at the seedling stage.

\section{Root characteristics and drought in cowpea}

Drought tolerance mechanisms in legume crops seem to be closely related to the root system or rooting pattern (Pandey et al. 1984, 1986; Itani et al. 1992; Silim and Saxena 1993; Matsui and Singh 2003). However, screening for root characteristics is difficult because of the underground distribution of root. The 'pin-board root-box' (Matsui and Singh 2003), herbicidal band screening (Robertson et al. 1985) and polyethylene glycol (PEG) (Badiane et al. 2004) methods were used to identify the role of cowpea root characteristics in drought tolerance. Typically, the evaluation of rooting characteristics has only been performed in a few cultivars when choosing parents for crosses or with a few promising advanced lines. With the herbicide-band screening the authors succeeded in detecting significant genotypic differences in mean numbers of days to first herbicide symptoms among five cowpea genotypes. Cowpea genotypes CB5 and 
Grant developed symptoms the earliest, 8006 and PI302457 developed symptoms the latest, and PI293579 was intermediate. The ranking of genotypes was consistent with estimates of relative depth of effective rooting obtained from soil moisture extraction measurements. With pin-board root-box screening two-dimensional distribution of roots can be studied. Important varietal differences were observed in cowpea architecture and some varieties have a well-spread deep root system while others have concentrated roots only on the upper soil strata. Although it has been reported that the results of this method is highly correlated with field observations (Matsui and Singh 2003), the pin-board root-box technique received much less attention compared to wooden box technique as described previously. This is probably because it is not practical to screen large number of plants. As root characteristics are important traits involved in drought avoidance, cowpea physiologists at IITA (Kano Station) and researchers from different areas are working to establish simple methods for root screening in cowpea.

Being a quantitatively inherited trait, an integrated screening approach as proposed by Slabbert et al. (2004) might be the most promising for phenotyping cowpea for drought tolerance. It is imperative that selected genotypes should always be tested in the field for confirmation of their yield performance under field drought. It would be helpful to identify traits that are associated with drought tolerance, but that are easier to measure and that have high heritability. Molecular markers closely linked to the loci with effects on these traits could be identified and later used in marker assisted selection (MAS) programs. However, any traits to be used in MAS programs for improving drought tolerance, must have a proven contribution to yield under drought conditions.

\section{Discovery of drought tolerance genes in cowpea}

The ability of cowpea to tolerate severe drought conditions and its relatively small nuclear genome size (estimated at $\sim 620 \mathrm{Mb}$ ) (Arumuganathan and Earle 1991) makes it an ideal model to study the molecular mechanisms of drought tolerance in crops. Several approaches can be utilized to identify genes that underlie drought tolerance in cowpea. One of the approaches would be to identify candidate genes that are known to be relevant to drought tolerance from previous studies in cowpea and other related crops and test its functionality in cowpea. Another and often-used approach is to identify differential expression of mRNAs in drought stressed versus control plants. Contrary to the candidate genes approach, differential expression of mRNA has been used in cowpea to identify genes that are involved in the drought response. Table 2 provides an overview on genes studied in cowpea in relation to drought stress that are further discussed below.

Iuchi et al. (1996a) isolated 24 cDNA clones that corresponded to dehydration-induced genes from cowpea variety IT84S-2246-4 by a differential screening method. Variety IT84S-2246-4 possesses higher drought tolerance and produces higher seed yield compared to other cultivars in semi-arid areas (Singh 1993). The cDNA clones represented ten different genes collectively named CPRD (cowpea clones responsive to dehydration) (Table 1). Nine of the CPRD genes were induced by drought, while one gene (CPRD29) was not. However, the timing of induction varied among the nine CPRD genes. Five of the cDNAs (CPRD8, CPRD14, CPRD22, CPRD12 and $C P R D 46)$ were further characterized by Iuchi et al. (1996a, b). Two additional novel drought-inducible genes were reported from the same cowpea variety (IT84S-2246-4) by Iuchi et al. (2000). One of these genes, VuNCED1, encodes a 9-cis-epoxycarotenoid dioxygenase that catalyzes the key step in ABA biosynthesis (Schwartz et al. 1997; Tan et al. 1997; Iuchi et al. 2000). Drought-stressed cowpea plants accumulated ABA to a level that was 160 times higher than that in unstressed plants. Both the accumulation of ABA and expression of $V u N C E D l$ were strongly induced by drought stress in 8-day-old cowpea plants, whereas drought stress did not trigger the expression of the $V u A B A l$ gene that encodes zeaxanthin epoxidase (Iuchi et al. 2000). Based on genomic Southernblot analysis, the $V u N C E D 1$ gene is part of a small gene family. The importance of this gene in drought stress response and tolerance of cowpea is, however, still to be proven (Iuchi et al. 2000).

The regulation of protein degradation through the use of protease-specific inhibitors is a common mechanism in metabolic processes and adaptive processes, including adaptation to drought stress in cowpea (Fernandes et al. 1993; Diop et al. 2004). To elucidate the role of the cowpea leaf protease 
Table 2 Overview of different genes identified as being involved in drought tolerance in cowpea

\begin{tabular}{|c|c|c|c|}
\hline $\begin{array}{l}\text { Gene } \\
\text { designation }\end{array}$ & $\begin{array}{l}\text { Accession } \\
\text { number }\end{array}$ & Gene function & Authors \\
\hline VuNCED1 & $(\mathrm{AB} 030293)$ & $\begin{array}{l}\text { 9-Cis-epoxycarotenoid dioxygenase catalyzes } \\
\text { the key step involved in ABA biosynthesis }\end{array}$ & Iuchi et al. (2000) \\
\hline CPRD86 & $(\mathrm{AB} 030294)$ & $\begin{array}{l}\text { 9-Cis-epoxycarotenoid dioxygenase catalyzes } \\
\text { the key step involved in ABA biosynthesis }\end{array}$ & Iuchi et al. (2000) \\
\hline VuABA1 & $(\mathrm{AB} 030295)$ & $\begin{array}{l}\text { Zeaxanthin epoxidase, an enzyme involved } \\
\text { in early step of ABA biosynthesis }\end{array}$ & Iuchi et al. (2000) \\
\hline CPRD12 & (D88121) & Cowpea response to dehydration stress & Iuchi et al. (1996b) \\
\hline CPRD46 & (D88122) & $\begin{array}{l}\text { Water stress-inducible gene for neoxanthin } \\
\text { cleavage enzyme involved in ABA biosynthesis }\end{array}$ & Iuchi et al. (1996b) \\
\hline CPRD8 & (D83970) & Cowpea response to dehydration stress & Iuchi et al. (1996a) \\
\hline CPRD14 & (D83971) & Cowpea response to dehydration stress & Iuchi et al. (1996a) \\
\hline CPRD22 & (D83972) & Cowpea response to dehydration stress & Iuchi et al. (1996a) \\
\hline dtGR & (DQ267474) & $\begin{array}{l}\text { Dual-targeted glutathione reductase key enzyme } \\
\text { involved in detoxication of (AOS) }\end{array}$ & Contour-Ansel et al. (2006) \\
\hline cGR & (DQ267475) & $\begin{array}{l}\text { Cytosolic glutathione reductase key enzyme } \\
\text { involved in detoxication of (AOS) }\end{array}$ & Contour-Ansel et al. (2006) \\
\hline VucAPX & (U61379) & $\begin{array}{l}\text { Cytosolic ascorbate peroxidase key enzyme } \\
\text { involved in detoxication of (AOS) }\end{array}$ & D'Arcy-Lameta et al. (2006) \\
\hline VupAPX & (AY466858) & $\begin{array}{l}\text { Peroxisomal ascorbate peroxidase key enzyme } \\
\text { involved in detoxication of (AOS) }\end{array}$ & D'Arcy-Lameta et al. (2006) \\
\hline VutAPX & (AY484492) & $\begin{array}{l}\text { Thylakoidal ascorbate peroxidase key enzyme } \\
\text { involved in detoxication of (AOS) }\end{array}$ & D'Arcy-Lameta et al. (2006) \\
\hline VusAPX & (AY484493) & $\begin{array}{l}\text { Stromatic ascorbate peroxidase key enzyme } \\
\text { involved in detoxication of (AOS) }\end{array}$ & D'Arcy-Lameta et al. (2006) \\
\hline VuPLD1 & (U92656) & $\begin{array}{l}\text { Putative phospholipase D a major lipid-degrading } \\
\text { enzyme in plant }\end{array}$ & El-Maarouf et al. (1999) \\
\hline VuPAP- $\alpha$ & (AF165891) & $\begin{array}{l}\text { PAP important for enzymic cascade leading } \\
\text { to membrane lipid degradation under environmental } \\
\text { stresses or senescence }\end{array}$ & Marcel et al. (2000) \\
\hline VuPAP- $\beta$ & (AF171230) & $\begin{array}{l}\text { PAP important for enzymic cascade leading } \\
\text { to membrane lipid degradation under environmental } \\
\text { stresses or senescence }\end{array}$ & Marcel et al. (2000) \\
\hline VuC1 & (AF278573) & $\begin{array}{l}\text { Protein inhibitors of cysteine proteinases belonging } \\
\text { to the papain family. }\end{array}$ & Diop et al. (2004) \\
\hline VuPAT1 & (AF193067) & $\begin{array}{l}\text { Galactolipid acyl hydrolase involves in membrane } \\
\text { degradation induced by drought stress }\end{array}$ & Matos et al. (2001) \\
\hline
\end{tabular}

inhibitor cystatin in response to abiotic stresses, $V$. unguiculata cultivars with contrasting response to water stress were subjected to controlled drought stress, desiccation and exogenous ABA. Expression of the cowpea cystatin gene was studied at the mRNA and protein level, using Northern blot and Western blot analysis (Diop et al. 2004). It was demonstrated that two cystatin transcripts were present in the leaves of stressed plants, which translated into two polypeptides. The polypeptide with the lowest molecular weight, which was also the weakest, corresponded in size to the deduced polypeptide of the VuC1 cDNA (the two-domain cystatin VUC1). Identity of the band with the highest molecular weight could not be determined. In cowpea seeds, multiple minor cystatin-like polypeptides were identified in addition to the major cystatin-like polypeptides of $25 \mathrm{kDa}$ (Flores et al. 2001). The authors concluded that this multiplicity of forms was related to multiple biological roles, as was also the case in rice (Kondo et al. 1990). 
In cowpea it has been shown that severe drought led to a massive degradation of membrane lipids (Monteiro de Paula et al. 1993). Phospholipase D (VuPLD1) the main enzyme responsible for the drought-induced degradation of membrane phopolipids was isolated and characterized from two cowpea cultivars (El-Maarouf et al. 1999). The expression and enzymatic activity of VuPLD1 gene were highly stimulated by drought stress in the susceptible cultivar $(1,183)$ and remained almost unchanged in the tolerant cultivar (EPACE-1). It seems that the drought-tolerant plants have the capacity to regulate the expression of enzymes responsible for the degradation of membrane lipids, which could be related to its previously shown capacity to maintain a remarkable stability of its membrane structure and functioning (Monteiro de Paula et al. 1993). From the leaves of the same cultivars, Matos et al. (2001) isolated a putative patatin-like (VuPAT1) gene encodes for galactolipid acyl hydrolase. The hydrolysis of galactolipids the main components of chloroplast membrane is stimulated by drought stress. The susceptible cultivar $(1,183)$ showed a rapid increase of VuPAT1 expression at mild drought stress while the tolerant (EPACE-1) was able to maintain lower levels of transcripts (Matos et al. 2001). This might be an indication of premature cell death and subsequently tissue death under water stress condition.

Two cDNAs encoding putative phosphatidate phosphatases (PAPs) designated VuPAP- $\alpha$ and $\mathrm{Vu}$ PAP- $\beta$ were cloned from cowpea leaves (Marcel et al. 2000). PAP is thought to play a role in the enzymatic cascade leading to membrane lipid degradation under environmental stresses or senescence (Todd et al. 1992; Sahsah et al. 1998). Unlike VuPAP- $\beta$, VuPAP- $\alpha$ has an N-terminal transit peptide and is targeted in vitro to the chloroplasts. The effect of water deficit on gene expression of VuPAP$\alpha$ and VuPAP- $\beta$ was studied in leaves of cowpea plants subjected to progressive drought by withholding water or in cut leaves subjected to rapid airdesiccation. Gene expression of VuPAP- $\alpha$ remained very low during the drought treatments, but was strongly stimulated on rehydration. VuPAP- $\beta$ expression did not vary in plants submitted to water stress by withholding irrigation, but increased rapidly in airdesiccated leaves (Marcel et al. 2000).

Water deficit (drought and desiccation) is known to induce the production of reactive oxygen species (ROS). Among these, $\mathrm{H}_{2} \mathrm{O}_{2}$ is produced mainly in the chloroplasts and mitochondria of stressed cells and is the source of major cell damage (Foyer et al. 1994; Dat et al. 2000). Among the detoxification systems two enzymes, glutathione reductase (GR) and ascorbate peroxidase (APX), play key roles. To study the variation in cytosolic and dual-targeted GR gene expression in the leaves, cowpea plants 'EPACE-1' (drought tolerant) and 1,183 (drought sensitive) were subjected to progressive drought, rapid desiccation and application of exogenous abscisic acid (ABA) (Contour-Ansel et al. 2006). Two new cDNAs encoding a putative dual-targeted (dtGR) and a cytosolic GR (cGR) were cloned and sequenced from leaves of $V$. unguiculata. Drought stress induced an up-regulation of the expression of the cGR gene directly related to the intensity of stress in both cultivars. The regulation of the expression of dtGR upon drought stress was different in a drought resistant cultivar (EPACE-1) compared with susceptible one $(1,183)$. In EPACE-1, the progression of the drought treatment down-regulated dtGR expression, whereas in the susceptible cultivar it highly stimulated dtGR expression, at least until moderate water stress was reached. In summary, these results demonstrate a noticeable activation in both cultivars of the antioxidant metabolism under progressive water stress, which in the susceptible cultivar 1,183 involves both GR genes.

Gazendam and Oelofse (2007) used suppression subtractive hybridization (SSH) on a drought tolerant (IT96D-602) and a susceptible (TVu7778) line to obtain differentially expressed transcripts. Preliminary sequencing revealed that four out of five randomly selected cDNA clones from this procedure coded for known genes found in a variety of plant species. Two are known to be stress-related genes glutathione-S-transferase (GST) and pathogenesis related protein-1 (PR-1). Analysis of additional clones may result in identification of more interesting differentially expressed genes with known protein functionality related to drought tolerance.

D’Arcy-Lameta et al. (2006) studied ascorbate peroxidases (APX) gene expression in response to progressive drought, rapid desiccation and application of exogenous abscisic acid in the leaves of the same cowpea varieties. Four new $V$. unguiculata cDNAs (Table 1) encoding putative cytosolic (VucAPX), peroxisomal ( $V u$ pAPX), chloroplastic (stromatic $V u$ sAPX) and thylakoidal ( $V u t \mathrm{APX})$ ascorbate peroxidases were 
isolated and characterized. The four cowpea APX deduced proteins were aligned and compared with a pea cytosolic APX (Mittler and Zilinskas 1991). Amino acid residues essential for enzymatic activity were conserved in the cowpea sequences $V u$ cAPX (Y62077) and pea (Jespersen et al. 1997; Shigeoka et al. 2002). Important increases in steady-state transcript levels of $V u \mathrm{cAPX}$ and $V u$ pAPX were observed after 2 h of ABA treatment and after 30 min of desiccation in 1,183, while in EPACE-1 air-desiccated leaves, no significant changes were observed in steady-state levels of $V u$ cAPX and $V u$ pAPX transcripts in response to rapid water loss and exogenous ABA treatment. Stimulation of the stromal isoform of 1,183 occurred much later, at severe water deficits. Chloroplastic APX gene expression was strongly stimulated already at low levels of water stress in EPACE-1. Although in the less-tolerant cowpea cultivar 1,183 the stimulation of chloroplastic APX genes occurred later than for EPACE-1 (D'ArcyLameta et al. 2006), the plant was still able to early activate the expression of genes coding for cytosolic isoforms. This shows that cowpea is a drought-tolerant species compared to other cultivated plants, and even the more sensitive cultivars have some level of resistance to water deficits.

Muchero et al. (2008) investigated the correlation of restriction fragment length polymorphisms markers derived from 12 known drought responsive cDNA in cowpea with seedling drought tolerance phenotypes. Such approach offers an opportunity to identify potential targets that would help to assign a specific contribution of cDNAs in conferring tolerance or susceptibility to drought stress. Putative fragments generated from CPRD12, CPRD46, galactolipid acyl hydrolas, phospholipase $\mathrm{D}$, and 9-cis-epoxycarotenoid dioxygenase (Table 1) showed promising correlations with drought related phenotypes. Such information would guide for further genetic studies and help plant breeders to select potential parents for generating mapping populations. Although drought tolerance is a highly quantitative trait, it has been demonstrated that the expression of a single gene can confer drought tolerance in plants. It was shown that over-expression of the AP2/ERF factors CBF1, DREB1A and CBF4 resulted in drought/salt/cold tolerance in Arabidopsis (Jaglo-Ottosen et al. 1998; Kasuga et al. 1999; Haake et al. 2002). AP2 transcription factor SHINE was shown to confer drought tolerance in Arabidopsis (Aharoni et al. 2004) using a different mechanism than that of the DREB/CBF genes. WXP1 is another AP2 domain containing transcription factor gene that increases cuticular wax accumulation and enhances drought tolerance in transgenic alfalfa (Medicago sativa) (Zhang et al. 2005). Further analysis of cowpea transgenic plants in which those above mentioned genes will be over-expressed or suppressed by antisense RNA should give more information on their functions under water stressed conditions in cowpea.

An important step elucidating the molecular mechanisms underlying the genetically complex abiotic stress responses such as drought is the rapid discovery of genes by the large-scale sequencing of randomly selected cDNA clones or expressed sequence tags (ESTs). There are now 183,000 EST as a result of the University of California Riverside (UCR) project, and the earlier IITA-Generation Challenge Program (GCP) project, from 13 genotypes. Recently, sequencing and analysis of the gene-rich, hypomethylated portion of the cowpea genome has been initiated (Timko et al. 2008). Over 250,000 gene-space sequence reads (GSRs) with an average length of 610 bp were generated. Sixty-two (62) out of Sixtyfour (64) well characterized plant transcription factor (TF) gene families are represented in the cowpea GSRs. The generated GSRs sequences may provide a source for functional markers in genes linked to drought tolerance traits in cowpea which could be used for marker-assisted selection.

\section{Breeding options to enhance drought tolerance in cowpea}

Attempts to improve drought tolerance of crops through conventional breeding programs have met with limited success because drought tolerance is physiologically and genetically a complex trait. The use of molecular markers to identify and locate different genes and genomic regions possessing factors which influence drought tolerance in cowpea will help to gain insight into the complex trait of drought tolerance. In addition these markers can be used to select for multiple traits and combine genes underlying these traits in cultivars with improved drought tolerance. These properties and prospects have initiated an increased interest in the application of Marker-Assisted Selection (MAS) for improving drought tolerance in many crops including cowpea. 
For better understanding of different biochemical and physiological pathways involved in drought tolerance in cowpea, three main approaches using molecular marker tools can be used.

The first approach assumes no prior knowledge about genes and is based on the so-called quantitative trait loci (QTL) method. On the most recent genetic map of cowpea (Ouédraogo et al. 2002), consisting of 11 linkage groups (LGs) spanning a total of 2,670 cM, with an average distance of approximately $6 \mathrm{cM}$ between markers, no genes/QTLs related to drought tolerance were mapped. However, different RIL populations are being currently screened at IITA for mapping and identification of QTLs with effects on drought tolerance across populations. The development of a set of ESTs from drought-stressed and non-stressed drought-sensitive and tolerant cowpea lines will be helpful in genotyping. The ESTs are utilized to develop other molecular markers such as simple sequence repeats (SSRs), single nucleotide polymorphisms (SNPs) and COS markers. The COS markers would facilitate cross-legume studies and allow better integration of cowpea into legume functional genomics. Currently cowpea genomics is receiving increased attention, which has resulted in projects that are producing large sets of ESTs and other genome sequences which has recently applied an Illumina Goldengate SNP array with 1,536 SNPs (UCR) to several RIL populations and diverse array of genotypes. This is an opportunity for the cowpea community to use a common set of markers in a wide collection of crosses and germplasm for construction of a densely populated consensus genetic map and for connecting genetics and QTLs/genes in cowpea. All the efforts in improving genetic maps and increasing available sequence data are only useful for QTL analysis if drought tolerance parameters can be measured as heritable traits. For cowpea these include the traits mentioned earlier like stomatal conductance, chlorophyll fluorescence, abscisic acid (ABA) levels, free proline levels, wooden box screening for drought tolerance at the seedling stage, and DLS.

The second approach is to make an 'educated guess' from published data, i.e., select candidate genes (CG) that are known to be functionally relevant for drought tolerance and test in cowpea plants whether these genes can be linked to drought tolerance. Candidate genes refer either to cloned genes presumed to affect a given trait ('functional
CGs') or to genes suggested by their close proximity on linkage maps to loci controlling the trait ("positional CGs') (Pflieger et al. 2001). The final validation of a CG will be provided through physiological analyses, and genetic transformation. The most detailed studies relating candidate genes to drought QTLs have looked at genes that determine ABA levels, at genes involved in dehydrin production, at invertase activity and transcription factors (Pflieger et al. 2001). However, there has also been interest in mapping a wide range of regulatory and structural candidate genes to determine QTLs with effects on drought tolerance and this approach has been particularly effective in the case of rice (Nguyen et al. 2004). As mentioned in Table 2, genes involved in ABA biosynthesis, ascorbate peroxidase, glutathione reductase and transferase, and putative phosphatidate phosphatases have been cloned from cowpea under water stress conditions. However, clear evidence that these genes affect drought tolerance for instance through transgenic analyses has not been reported so far. Other CGs can be inferred from studies in related crops and model crops. Cowpea orthologues of these genes that have been characterized in other species and crops as being involved in drought tolerance will be increasingly easy to discover, as the number of cowpea EST sequences as well as genespace sequences is increasing rapidly. An interesting group of GCs are transcription factors that are involved in the drought response including $M y b$ genes, WRKY genes, $A P 2$ and $E R F$ genes.

The third approach is comparative genomics. Earlier studies indicated that members of Papilionoideae subfamily to which cowpea belongs exhibit extensive genome conservation, based on comparative genome analysis between mungbean and cowpea (MenancioHautea et al. 1993), between pea and lentil and orthologous seed weight genes in cowpea and mungbean (Fatokun et al. 1992). Recent advances in comparative mapping among the legumes has clarified the genetic relationship of model and crop legumes and enabled linking of the genomes of the tropical and temperate legumes that represent the major clades of the legume family (Choi et al. 2004a, b). Drought tolerance is a highly appropriate target for comparative plant genomics because this information-rich approach has the potential to unveil the key genetic contributors to the complex physiological processes involved (Bennetzen 2000). With the already extensive and 
rapidly increasing publicly available genomic data for cowpea, comparative genomics of cowpea with other legumes such as common bean (Blair et al. 2002; Schneider et al. 1997) and soybean (Mian et al. 1996, 1998; Specht et al. 2001) could be applied. This will allow aligning of drought QTLs between legume species including cowpea and determine the most important regions for saturated mapping. Moreover, the micro and macrosyntenic relationships detected between cowpea and other cultivated and model legumes (Timko et al. 2008) would simplify the identification of informative markers for markerassisted trait selection and map-based gene isolation necessary for cowpea improvement.

\section{Conclusion}

A multidisciplinary approach including breeding, physiology and biotechnology is required for efficient germplasm improvement for drought tolerance in cowpea. Concerted efforts are being made worldwide to develop drought tolerant cowpea varieties. At IITA RIL mapping populations are being used to identify markers associated with QTLs with effects on different traits with particular emphasis given to the genetic dissection of both yield component and physiological drought adaptive traits.

Important drought related cDNAs and genes have been isolated from cowpea. The advances that are currently being made in cowpea genomics will unlock even more candidate genes. The next step will be to select promising candidate genes and functionally characterize these genes. For candidate genes with well-known functions functional markers can be used for MAS. The molecular analysis of drought responses in plants has reached a stage where research can now build upon a large collection of well characterized genes. The use of novel approaches combining genetic, physiological, biochemical, and molecular techniques should provide exciting results in the development of drought tolerant cowpea varieties in the near future.

Acknowledgments This review work was carried out under the International Institute of Tropical Agriculture (IITA)-WUR Lukas Brader Fellowship, with contribution of the Leventis Foundation, the Government of Italy, IFAR and individual members of the IITA Board. The support of Wageningen UR Plant Breeding is gratefully acknowledged.
Open Access This article is distributed under the terms of the Creative Commons Attribution Noncommercial License which permits any noncommercial use, distribution, and reproduction in any medium, provided the original author(s) and source are credited.

\section{References}

Aharoni A, Dixit S, Jetter R, Thoenes E, Arkel G, Pereira A (2004) The SHINE Clade of AP2 Domain Transcription Factors Activates Wax Biosynthesis, Alters Cuticle Properties, and Confers Drought Tolerance when Overexpressed in Arabidopsis. Plant Cell 16:2463-2480. doi:10.1105/tpc. 104.022897

Anyia AO, Herzog H (2004) Genotypic variability in drought performance and recovery in cowpea un controlled environment. J Agron Crop Sci 190:151-159. doi:10.1111/ j.1439-037X.2004.00096.x

Arumuganathan K, Earle ED (1991) Nuclear DNA content of some important plant species. Plant Mol Biol Rep 9:208218. doi:10.1007/BF02672069

Ashley J (1993) Drought and crop adaptation. In: Rowland JRJ (ed) Dryland farming in Africa. Macmillan Press Ltd, UK, pp 46-67

Badiane FA, Diouf D, Sané D, Diouf O, Goudiaby V, Diallo N (2004) Screening cowpea [Vigna unguiculata (L.) Walp.] varieties by inducing water deficit and RAPD analyses. Afr J Biotechnol 3(3):174-178

Bates LM, Hall AE (1981) Stomatal closure with soil water depletion not associated with changes in bulk leaf water status. Oecologia 50:62-65. doi:10.1007/BF00378794

Bennetzen JL (2000) Comparative genomics approaches to the study of drought tolerance. In: Ribaut JM, Poland D (eds) Molecular approaches for the genetic improvement of cereals for stable production in water limited environments: strategic planning workshop held at CIMMYT, El Batan, México, 21-25 June 1999

Blair MW, Muñoz MC, Beebe SE (2002) QTL analysis of drought and abiotic stress tolerance in common bean RIL populations. In: Annual report, Biotechnology Research Project. CIAT, Cali, Colombia, pp 68-72

Blum A (1983) Genetic and physiological relationships in plant breeding for drought tolerance. Agric Water Manage 7:195-205. doi:10.1016/0378-3774(83)90083-5

Blum A (1985) Breeding crop varieties for stress environments. Crit Rev Plant Sci 2:199-238. doi:10.1080/073526 88509382196

Boyer JS (1996) Advances in drought tolerance in plants. Adv Agron 56:189-218

Carsky RJ, Singh BB, Oyewole B (2001) Contribution of early season cowpea to late season maize in the savanna zone of West Africa. Biol Agric Hortic 18:303-315

Choi HK, Kim D, Uhm T, Limpens E, Lim H, Mun JH, Kalo P, Penmetsa RV, Seres A, Kulikova O et al (2004a) A sequence-based genetic map of Medicago truncatula and comparison of marker colinearity with $M$. sativa. Genetics 166:1463-1502. doi:10.1534/genetics.166.3.1463 
Choi HK, Mun JH, Kim DJ, Zhu H, Baek JM, Mudge J, Roe B, Ellis N, Doyle J, Kiss GB, Young ND, Cook DR (2004b) Estimating genome conservation between crop and model legume species. Proc Natl Acad Sci USA 101:1528915294. doi:10.1073/pnas.0402251101

Cisse N, Ndiaye M, Thiaw S, Hall AE (1997) Registration of _Melakh_cowpea. Crop Sci 37:1978

Condon AG, Hall AE (1997) Adaptation to diverse environments: variation in water-use efficiency within crop species. In: Jackson LE (ed) Ecology in agriculture. Academic Press, San Diego, pp 79-116

Contour-Ansel D, Torres-Franklin ML, Cruz De Carvalho MH, D'Arcy-Lameta A, Zuily-fodil Y (2006) Glutathione reductase in leaves of cowpea: cloning of two cDNAs, expression and enzymatic activity under progressive drought stress, desiccation and abscisic acid treatment. Ann Bot (Lond) 98:1279-1287. doi:10.1093/aob/mcl217

Cruz de Carvalho MH, Laffray D, Louguet P (1998) Comparison of the physiological responses of Phaseolus vulgaris and Vigna unguiculata cultivars when submitted to drought conditions. Environ Exp Bot 40:197-207. doi: 10.1016/S0098-8472(98)00037-9

D'Arcy-Lameta A, Ferrari-Iliou R, Contour-Ansel D, PhamThi AT, Zuily-Fodil Y (2006) Isolation and characterization of four ascorbate peroxidase cDNA responsive to water deficit in cowpea leaves. Ann Bot 97:133-140

Dat J, Vandenabeele S, Vranova E, Van Montagu M, Inze D, Van Breusegem F (2000) Dual action of the active oxygen species during plant stress response. Cell Mol Life Sci 57: 779-795

Diop NN, Kidric M, Repellin A, Gareil M, D’Arcy-Lameta A, Pham Thi AT, Zuily-Fodil Y (2004) A multicystatin is induced by drought-stress in cowpea (Vigna unguiculata (L.) Walp.) leaves. FEBS Lett 577:545-550

Ehlers JD, Hall AE (1997) Cowpea (Vigna unguiculata L. Walp.). Field Crops Res 53:187-204

El-Maarouf H, Zuily-Fodil Y, Gareil M, D’Arcy-Lameta A, Pham Thi AT (1999) Enzymatic activity and gene expression under water stress of phospholipase D in two cultivars of Vigna unguiculata L. Walp. differing in drought tolerance. Plant Mol Biol 39:1257-1265

Ewansiha SU, Singh BB (2006) Relative drought tolerance of important herbaceous legumes and cerealsin the moist and semi-arid regions of West Africa. J Food Agric Environ 4:188-190

FAO (2004) FAO statistical databases. Available from http://faostat.fao.org/faostat/default.jsp. Accessed 3 June 2008

Fatokun CA, Menancio-Hautea DI, Danesh D, Young ND (1992) Evidence for orthologous seed weight genes in cowpea and mungbean based on RFLP mapping. Genetics 132:841-846

Fernandes KVS, Sabelli PA, Barett DHP, Richardson M, Xavier-Filho J, Shewry PR (1993) The resistance of cowpea seeds to bruchid beetles is not related to levels of cysteine proteinase inhibitors. Plant Mol Biol 23:215-219

Fischer RA, Wood JT (1979) Drought tolerance in spring wheat cultivars. III. Yield associations with morphological traits. Aust J Agric Res 30:1000-1020

Flores VMQ, Louro RP, Xavier-Filho J, Barratt DHP, Shewry PR, Fernandes KVS (2001) Temporal and tissue localization of a cowpea (Vigna unguiculata) cystatin. Physiol Plant 112:195-199

Foyer CH, Lelandais M, Kunert KJ (1994) Photoxidative stress in plants. Physiol Plant 92:696-717

Fussell LK, Bidinger FR, Bieler P (1991) Crop physiology and breeding for drought tolerance: research and development. Field Crops Res 27:183-199

Gazendam I, Oelofse D (2007) Isolation of cowpea genes conferring drought tolerance: construction of a cDNA drought expression library. Water SA 33(3):387-391

Glantz MH (1987) Drought and hunger in Africa. Cambrige University Press, Cambrige, pp 43-47

Gwathmey CO, Hall AE, Madore MA (1992) Adaptive attributes of cowpea genotypes with delayed monocarpic leaf senescence. Crop Sci 32:765-772

Haake V, Cook D, Riechmann JL, Pineda O, Thomashow MF, Zhang JZ (2002) Transcription factor CBF4 is a regulator of drought adaptation in Arabidopsis. Plant Physiol 130: 639-648

Hall AE, Patel PN (1985) Breeding for resistance to drought and heat. In: Singh SR, Rachie KO (eds) Cowpea research, production and utilization. Wiley, New York, pp 137-151

Hall AE, Schulze ED (1980) Drought effects on transpiration and leaf water status of cowpea in controlled environments. Aust J Plant Physiol 7:141-147

Hall AE, Mutters RG, Hubick KT, Farquhar GD (1990) Genotype differences in carbon isotope discrimination by cowpea under wet and dry fi eld conditions. Crop Sci 30: 300-305

Hall AE, Singh BB, Ehlers JD (1997a) Cowpea breeding. Plant Breed Rev 15:215-274

Hall AE, Thiaw S, Ismail AM, Ehlers JD (1997b) Water-use efficiency and drought adaptation of cowpea. In: Singh BB (ed) Advances in cowpea research. IITA, Ibadan, pp 87-98

Hamidou F, Zombre G, Braconnier S (2007) Physiological and biochemical responses of cowpea genotypes to water stress under glasshouse and field conditions. J Agron Crop Sci 193:229-237

Hartung W, Schiller P, Karl-Josef D (1998) Physiology of poikilohydric plants. Prog Bot 59:299-327

Hounam CE, Burgos JJ, Kalik MS, Parmer WC, Rodda J (1975) Drought and agriculture. Secretariat of the World Meteorological Organisation, Geneva, pp 1-11 (W.M.O. no 392)

Itani J, Utsunomiya N, Shigenaga S (1992) Drought tolerance of cowpea. I. Studies on water absorption ability of cowpea (Vigna unguiculata (L.) Walp. var. unguiculata). Jpn J Trop Agric 36:37-44

Iuchi S, Yamaguchi-Shinozaki K, Urao T, Tereo T, Shinozaki K (1996a) Novel drought inducible genes in the highly drought-tolerant cowpea: cloning of cDNA and analysis of their gene expression. Plant Cell Physiol 37:1073-1082

Iuchi S, Yamaguchi-Shinozaki K, Urao T, Shinozaki K (1996b) Characterization of two cDNA for novel drought-inducible genes in the highly tolerant cowpea. J Pant Res 109: 415-424

Iuchi S, Kobayashi M, Yamaguchi-Shinozaki K, Shinozaki K (2000) A stress-inducible gene for 9-cis-epoxycartenoid dioxygenase involved in abscisic acid biosynthesis under water stress in drought tolerant cowpea. Plant Physiol 123: $553-562$ 
Jaglo-Ottosen KR, Gilmour SJ, Zarka DG, Schabenberger O, Thomashow MF (1998) Arabidopsis CBF1 overexpression induces COR genes and enhances freezing tolerance. Science 280:104-106

Jespersen HM, Kjaersgard IVH, Ostergaard L, Welinder KG (1997) From sequence analysis of three novel ascorbate peroxidases from Arabidopsis thaliana to structure, function and evolution of seven types of ascorbate peroxidase. Biochem J 326:305-310

Kasuga M, Liu Q, Miura S, Yamaguchi-Shinozaki K, Shinozaki K (1999) Improving plant drought, salt, and freezing tolerance by gene transfer of a single stress-inducible transcription factor. Nat Biotech 17:287-291

Kondo H, Abe K, Nishimura I, Watanabe H, Emori Y, Arai S (1990) Two distinct cystatin species in rice seeds with different specificities against cysteine proteinases. Molecular cloning, expression, and biochemical studies on oryzacystatin-II. J Biol Chem 265:15832-15837

Krishnamurthy LC, Johansen C, Ito O (1996) Genotypic variation in root system development and its implication for drought resistance in Chickpea. In: Ito O, Johansen C, Adu-Gyamfi JJ, Katayama K, Kumar Rao JVK, Rego TJ (eds) Roots and nitrogen in cropping systems of the semiarid tropics. JIRCAS and ICRISAT, Hyderabad, pp 235-250

Kulkarni MJ, Prasad TG, Sashidhar VR (2000) Genotypic variation in early warning signals from roots in drying soil: intrinsic differences in ABA synthesising capacity rather than root density determines total ABA message in cowpea (Vigna unguiculata L.). Ann appl Biol 136:267-272

Kuykendall LD, Hashem FM, Dadson RB, Elkan GK (2000) Nitrogen fixation. In: Lederberg $\mathbf{J}$ (ed) Encyclopedia of microbiology, vol 3. Academic Press, New York, pp 329-404

Langyintuo AS, Lowenberg-DeBoer J, Faye M, Lambert D, Ibro G, Moussa B, Kergna A, Kushwaha S, Musa S, Ntoukam G (2003) Cowpea supply and demand in West and Central Africa. Field Crop Res 82(2003):215-231

Lawan RJ (1983) Responses of four grain legumes to water stress in higher plants. Annu Rev Plant Physiol 35:299319

Lu Z, Percy RG, Qualset CO, Zeiger E (1998) Stomatal conductance predicts yields in irrigated pima cotton and bread wheat grown at high temperatures. J Exp Bot 49:453-460

Mai-Kodomi Y, Singh BB, Myers O Jr, Yopp JH, Gibson PJ, Terao T (1999a) Two mechanisms of drought tolerance in cowpea. Indian J Genet 59:309-316

Mai-Kodomi Y, Singh BB, Terao T, Myers O Jr, Yopp JH, Gibson PJ (1999b) Inheritance of drought tolerance in cowpea. Indian J Genet 59:317-323

Marcel GCF, Matos A, D'Arcy-Lameta A, Kader JC, ZuilyFodil Y, Pham-Thi A (2000) Two novel plant cDNAs homologous to animal type-2 phosphatidate phosphatase are expressed in cowpea leaves and are differently regulated by water deficits. Biochem Soc Trans 28:915-917

Martins LMV, Xavier GR, Rangel FW, Ribeiro JRA, Neves MCP, Morgado LB, Rumjanek NG (2003) Contribution of biological fixation to cowpea: a strategy for improving seed yield in the semi-arid region of Brazil. Biol Fertil Soils 38:333-339
Matos AR, D'Arcy-Lameta A, Franca M, Petres S, Edelman L, Kader JC, Zuily-Fodil Y, Pham-Thi AT (2001) A novel patatin-like gene stimulated by drought stress encodes a galactolipid acyl hydrolase. FEBS Lett 491:188-192

Matsui T, Singh BB (2003) Root characteristics in cowpea related to drought tolerance at the seedling stage. Expl Agric 39:29-38

Menancio-Hautea D, Fatokun CA, Kumar L, Danesh D, Young ND (1993) Comparative genome analysis of mungbean (Vigna radiata L. Wilczek) and cowpea (Vigna unguiculata L.) using RFLP mapping data. Theoret Appl Genet 86:797-810

Mian MAR, Bailey MA, Ashley DA, Wells R, Carter JE, Parrott WA, Boerma HR (1996) Molecular markers associated with water use efficiency and leaf ash in soybean. Crop Sci 36:1252-1257

Mian MAR, Ashley DA, Boerma HR (1998) An additional QTL for water use efficiency in soybean. Crop Sci 38: 390-393

Mitra J (2001) Genetics and genetic improvement of drought resistance of crop plants. Curr Sci 80:758-763

Mittler R, Zilinskas BA (1991) Molecular cloning and nucleotide sequence analysis of a cDNA encoding pea cytosolic ascorbate peroxidase. FEBS Lett 289:257-259

Monteiro de Paula F, Pham Thi AT, Zuily-Fodil Y, Ferrarilliou R, Vieira Da Silva J, Mazliak P (1993) Effect of water stress on biosynthesis and degradation of polyunsaturated lipid molecular species of Vigna unguiculata. Plant Physiol Biochem 31:707-715

Morgan JM, Rodriguez-Maribona B, Knights EJ (1991) Adaptation to water deficit in chickpea breeding lines by osmoregulation: relationship to grain yields in the field. Field Crops Res 27:61-70

Mortimore MJ, Singh BB, Harris F, Balde SF (1997) Cowpea in traditional cropping systems. In: Singh BB, Mohan Raj DR, Dashiell KE, Jackai LEN (eds) Advances in cowpea research, Co-publication of International Institute of Tropical Agriculture (IITA), Ibadan, Nigeria and Japan International Research Centre for Agricultural Sciences (JIRCAS), Sayce Publishing, Devon, pp 99-113

Muchero W, Ehlers JD, Roberts PA (2008) Seedling stage drought-induced phenotypes and drought-responsive genes in diverses cowpea genotypes. Crop Sci 48:541-552

Ng NQ, Marechal R (1985) Cowpea taxonomy, origin and germ plasm. In: Singh SR, Rachie KO (eds) Cowpea research, production and utilization, John Wiley and Sons Ltd., NY, pp 11-21

Nguyen TTT, Klueva N, Chamareck V, Aarti A, Magpantay G, Millena ACM, Pathan MS, Nguyen HT (2004) Saturation mapping of QTL regions and identification of putative candidate genes for drought tolerance in rice. Mol Genet Genomics 272:35-46

Ogbonnaya CI, Sarr B, Brou C, Diouf O, Diop NN, Roy-Macauley H (2003) Selection of Cowpea Genotypes in Hydroponics, Pots, and Field for Drought Tolerance. Crop Sci 43:1114-1120

Okosun LA, Aken'ova ME, Singh BB (1998a) Screening for drought tolerance at seedling stage in cowpea (Vigna unguiculata [L.] Walp. I.). The significance of the trait permanent wilting percentage. J Arid Agric 8:1-10 
Okosun LA, Aken'ova ME, Singh BB (1998b) Screening for drought tolerance at seedling stage in cowpea (Vigna unguiculata [L.] Walp. I.). Selecting for root length and recovery ability traits. J Arid Agric 8:11-20

Ouédraogo JT, Gowda BS, Jean M, Close TJ, Ehlers JD, Hall AE, Gillespie AG, Roberts PA, Ismail AM, Bruening G, Gepts P, Timko MP, Belzile FJ (2002) An improved genetic linkage map for cowpea (Vigna unguiculata L.) combining AFLP, RFLP, RAPD and Biochemical markers. Genome 45:175-188

Pandey RK, Pendleton JW (1986) Genotypic variation in root and shoot growth of peanut in hydroponics. Philipp J Crop Sci 11:189-193

Pandey RK, Herrera WAT, Villegas AN, Pendleton JW (1984) Drought response of grain legumes under irrigation gradient. III. Plant growth. Agron J 76:557-560

Pflieger S, Lefebvrel V, Mathilde Causse M (2001) The candidate gene approach in plant genetics. Mol Breed 7:275-291

Robertson BM, Hall AE, Foster KW (1985) A field technique for screening for genotypic differences in root growth. Crop Sci 25:1084-1090

Sahsah Y, Campos P, Gareil M, Zuily-Fodil Y, Pham Thi AT (1998) Enzymatic degradation of polar lipids in Vigna unguiculata leaves and influence of drought stress. Physiol Plant 104:577-586

Schneider KA, Brothers ME, Kelly JD (1997) Marker-assisted selection to improve drought tolerance in common bean. Crop Sci 37:51-60

Schwartz SH, Tan BC, Gage DA, Zeevaart JA, McCarty DR (1997) Specific oxidative cleavage of carotenoids by VP14 of maize. Science 276:1872-1874

Selvaraj U, Annappan RS, Giridharan S (1986) A new high yielding drought tolerant cowpea variety. Madras Agric J 73:125-128

Shackel KA, Hall AE (1979) Reversible leaflet movements in relation to drought adaptation of cowpeas, Vigna unguiculata (L.) Walp. Aust J Plant Physiol 6:265-276

Shigeoka S, Ishikawa T, Tamoi M, Miyagawa Y, Takeda T, Yabuta Y et al (2002) Regulation and function of ascorbate peroxidase isoenzymes. J Exp Bot 53:1305-1319

Silim SN, Saxena MC (1993) Adaptation of spring-sown chickpea to the Mediterranean basin. II. Factors influencing yield under drought. Field Crops Res 34:137-146

Singh BB (1987) Breeding cowpea varieties for drought escape. In: Menyonga JM, Bezuneh T, Youdeowei A (eds) Food seed production in semi arid Africa. OAU/STRCSAFGRAD, Ouagadougou, pp 299-306

Singh BB (1993) The cowpea breeding section of the archivalt (1988-1992) of the grain legume improvement program. International Institute of Tropical Agriculture, Ibadan

Singh BB (1994) Breeding suitable cowpea varieties for West and Central African savanna. In: Menyonga JM, Bezuneh JB, Yayock JY, Soumana I (eds) Progress in food grains research and production in semiarid Africa. OAU/STRCSAFGRAD, Ouagadougou, pp 77-85

Singh BB, Chambliss OL, Sharma B (1993) Recent advances in cowpea breeding. In: Singh BB, Mohan Raj DR, Dashiell KE, Jackei LEN (eds) Advances in cowpea research. Copulation of the International Institute of Tropical Agriculture (IITA) and Japan International Research Center for Agricultural Sciences (JIRCAS). IITA, Ibadan, pp 30-49
Singh BB, Chambliss OL, Sharma B (1997) Recent advances in cowpea breeding. In: Singh BB, Mohan Raj DR, Dashiell KE, Jackai LEN (eds) Advances in cowpea research, Co-publication of International Institute of Tropical Agriculture (IITA), Ibadan, Nigeria and Japan International Research Centre for Agricultural Sciences (JIRCAS), Sayce Publishing, Devon, pp 114-128

Singh BB, Mai-Kodomi Y, Terao T (1999a) A simple screening method for drought tolerance in cowpea. Indian J Genet 59:211-220

Singh BB, Mai-Kodomi Y, Terao T (1999b) Relative drought tolerance of major rainfed crops of the semi-arid topics. Indian J Genet 59(4):437-444

Singh BB, Hartmann P, Fatokun C, Tamo M, Tarawali SA, Ortiz R (2003a) Recent progress in cowpea improvement. Chron Hortic 43:8-12

Singh BB, Ajeigbe HA, Tarawali SA, Fernandez-Rivera S, Abubakar M (2003b) Improving the production and utilization of cowpea as food and fodder. Field Crops Res 84:169-177

Slabbert R, Spreeth M, Krüger GHJ (2004) Drought tolerance, traditional crops and biotechnology: breeding towards sustainable development. S Afr J Bot 70:116-123

Souza RP, Machado EC, Silva JAB, Lagoa AMMA, SIlveira JAG (2004) Photosynhtetic gas exchange, chlorophyll fluorescence and some associated metabolic changes in cowpea (Vigna unguiculata) during water stress and recovery. Environ Exp Bot 51:45-56

Specht JE, Chase K, Macrander M, Graef GL, Chung J, Markwell JP, Germann M, Orf JH, Lark KG (2001) Sobyean response to water: a QTL analysis of drought tolerance. Crop Sci 41:493-509

Tan BC, Schwartz SH, Zeevaart JA, McCarty DR (1997) Genetic control of abscisic acid biosynthesis in maize. Proc Natl Acad Sci USA 94:12235-12240

Thiaw S, Hall AE, Parker DR (1993) Varietal intercropping and the yields and stability of cowpea production in semiarid Senegal. Field Crops Res 33:217-233

Timko MP, Rushton PJ, Laudeman TW, Bokowiec MT, Chipumuro E, Cheung F, Town CD, Chen X (2008) Sequencing and analysis of the gene-rich space of cowpea. BMC Genomics 9:103 (http://www.biomedcentral. com/1471-2164/9/103)

Todd JF, Paliyath G, Thompson JE (1992) Effect of chilling on the activities of lipid degrading enzymes in tomato fruit microsomal membranes. Plant Physiol Biochem 30:517-522

Tomar SMS, Kumar GT (2004) Seedling survivability as a selection criterion for drought tolerance in wheat. Plant Breed 123:392-394

Turk KJ, Hall AE (1980) Drought adaptation of cowpea: II. Influence of drought on plant water status and relations with seed yield. Agron J 72:421-427

Turk KJ, Hall AE, Asbell CW (1980) Drought adaptation of cowpea. Influence of drought on seed yield. Agron J 29: 413-420

Turner NC, Wright GC, Siddique KHM (2000) Adaptation of grain legumes (pulses) to water-limited environments. Adv Agron 71:193-231

Yancey PH, Clark ME, Hand SC, Bowlus PD, Somero GN (1982) Living with water stress: evolution of osmolyte system. Science 217:1214-1217 
Zhang JY, Broeckling CD, Blancaflor EB, Sledge MK, Sumne LW, Wang ZY (2005) Overexpression of WXP1, a putative Medicago truncatula AP2 domain-containing transcription factor gene, increases cuticular wax accumulation and enhances drought tolerance in transgenic alfalfa (Medicago sativa). Plant J 42:689-707 